Review Article

\title{
A Review on Development Prospect of CZTS Based Thin Film Solar Cells
}

\author{
Xiangbo Song, Xu Ji, Ming Li, Weidong Lin, Xi Luo, and Hua Zhang \\ Solar Energy Research Institute, Yunnan Normal University, Kunming 650092, China \\ Correspondence should be addressed to Xu Ji; jixu@ynnu.edu.cn
}

Received 5 December 2013; Accepted 6 March 2014; Published 26 May 2014

Academic Editor: David Lee Phillips

Copyright (C) 2014 Xiangbo Song et al. This is an open access article distributed under the Creative Commons Attribution License, which permits unrestricted use, distribution, and reproduction in any medium, provided the original work is properly cited.

$\mathrm{Cu}_{2} \mathrm{ZnSnS}_{4}$ is considered as the ideal absorption layer material in next generation thin film solar cells due to the abundant component elements in the crust being nontoxic and environmentally friendly. This paper summerized the development situation of $\mathrm{Cu}_{2} \mathrm{ZnSnS}_{4}$ thin film solar cells and the manufacturing technologies, as well as problems in the manufacturing process. The difficulties for the raw material's preparation, the manufacturing process, and the manufacturing equipment were illustrated and discussed. At last, the development prospect of $\mathrm{Cu}_{2} \mathrm{ZnSnS}_{4}$ thin film solar cells was commented.

\section{Introduction}

With the increasing consumption of conventional energy and the gradually serious environmental crisis, the research and application of solar cells attracted a worldwide attention. In the past ten years, the progress of the thin film preparation technology promoted the technology of the second generation solar cells based on semiconductor thin film materials to flourish. Due to the demand for less material, the thin film solar cell technology can effectively reduce the cost of materials. Moreover, the thin film materials can flexibly deposit on substrates such as glass, stainless steel, and plastic, especially suitable for solar building integration.

Currently, the main thin film solar cells include the amorphous silicon thin film, cadmium telluride (CdTe), copper indium selenium (CIS), copper indium gallium selenium (CIGS), the gallium arsenide, and the copper zinc tin sulfur $\left(\mathrm{Cu}_{2} \mathrm{ZnSnS}_{4}\right.$ is hereafter referred to as CZTS), and, so forth, the gallium arsenide and cadmium telluride contain toxic elements (cadmium and arsenic) and copper indium gallium selenide system contains rare indium elements; thus, these two types of solar cells cannot meet the future development of solar cells. The CZTS is quaternary compounds of stannite structure; its band gap is about $1.50 \mathrm{ev}$, which is very close to the best band gap required by semiconductor solar cells $(1.35 \mathrm{eV})$. CZTS is the direct band gap semiconductor material with a high absorption coefficient and a multilayer structure; thus, it can be employed in the absorption layer of thin film solar cells. Compared with the currently commercialized crystalline silicon CdTe CIGS, due to its abundant component elements in the earth crust, nontoxic and environmentally friendly CZTS thin film solar cells are one of the best candidate materials for solar absorbing layer [1-3], which is expected to become the ideal absorption layer material of next generation thin film solar cells.

In 1977, the $\mathrm{Cu}_{2} \mathrm{CdSnS}_{4}$ based monocrystalline solar cells were successfully fabricated and reached the efficiency of $1.6 \%$ in Bell Lab [4]. Ito and Nakazawa in Japan Shinshu University utilized the synthesized $\mathrm{Cu}_{2} \mathrm{CdSnS}_{4}$ monocrystal to achieve an open circuit voltage of $165 \mathrm{mV}$ in 1988 [5]. In 1997, Katagiri et al. synthesized p-type conductivity with a band gap of $1.45 \mathrm{eV}$ and the absorption coefficient over $10^{4} \mathrm{~cm}^{-1}$ and obtained the conversion efficiency of $0.66 \%$ $[6,7]$. However, the existence range of single-phase based CZTS is small and quaternary synthesis is difficult, so it is no new breakthrough for quite a long time, such as the band structure, defect type, and so on. It is still under investigation.

In recent years, the $\mathrm{CuInSe}_{2}$ cells have reached more than $10 \%$ components efficiency and obtained a certain amount of industry expectation. Indium resources were increasingly scarce with the expansion of the tablet display area, and people have strengthened the study on CZTS. With Veeco 
of CIGS equipment manufacturers quitting from the CIGS in August 2011 for a too long period of commercialization and cost reduction, the United States CIGS PV module supplier Solyndra Company applied for bankruptcy, and the CZTS attracted more attention.

The mature vacuum coating technology in CIGS solar cells has been successfully employed in the CZTS thin film solar cells. Nagaoka University of Technology in Japan utilized the atomic-beam evaporation and sputtering method to achieve a conversion efficiency of around $6 \%$. But vacuum lines were still unable to avoid expensive equipment. In search of lower cost cells, people began experimenting with different liquid nonvacuum deposition methods in the recent two years and achieved a conversion efficiency of $11.2 \%$ in small scale CZTS solar cells. Hereafter the CZTS had aroused the latent commercial interests. For example, IBM and the subsidiary of Showa Shell-Solar Frontier joined hands to exploit nonvacuum deposition technology for CZTS. Solar Frontier had extensive experience in CIS thin film PV technology development and industry. Moreover, IBM announced that it would also work with DelSolar to develop CZTS technology. The AQT Solar of U.S. announced that its conversion efficiency of CZTS film solar was close to $10 \%$ by vacuum sputtering method and began the commercialization process of products. On November 21, 2012, Korea DGIST developed a vacuum deposition coating craft which can be applied in the common production, and they had successfully fabricated the CZTS thin film solar cells with a photoelectric conversion efficiency of $8 \%$ higher than the world's highest conversion efficiency at that time. DGIST announced that this would be a huge boost for the expansion of solar cell market.

\section{Materials and Methods}

\subsection{Chemical and Physical Properties of CZTS}

2.1.1. Crystal Structure of CZTS. $\mathrm{Cu}_{2} \mathrm{ZnSnS}_{4}$ is the quaternary compound semiconductor of stannite structure, and its main ingredient is the mixture of $\mathrm{Cu}_{2} \mathrm{FeSnS}_{4}$ and $\mathrm{Cu}_{2} \mathrm{ZnSnS}_{4}$. Generally, stannite presents steel gray with slight olive green metallic luster, usually in the form of grain bulk. It mainly occurs in hydrothermal deposits in Cornwall and Bolivia, UK.

In 1960, Pamplin had proposed stannite $\left(\mathrm{Cu}_{2} \mathrm{FeSnS}_{4}\right)$ quaternary compound semiconductor structures [8] of ultracrystal pack in Nature. It was not until 1974 that Schäfer and Nitsche had fabricated $\mathrm{Cu}_{2} \mathrm{ZnSnS}_{4}$ for the first time [9]. Parasyuk et al. presented that there was only one phase $\left(\mathrm{Cu}_{2} \mathrm{ZnGeS}_{4}\right)$ existing in the $\mathrm{Cu}_{2} \mathrm{~S}-\mathrm{ZnS}-\mathrm{GeS}_{2}$ system and two quaternary intermediate phases, $\mathrm{Cu}_{2} \mathrm{CdGeS}_{4}$ and $\sim \mathrm{Cu}_{8} \mathrm{CdGeS}_{7}$, existed in the $\mathrm{Cu}_{2} \mathrm{~S}-\mathrm{CdS}-\mathrm{GeS}_{2}$ system, when the isothermal section of the $\mathrm{Cu}_{2} \mathrm{~S}-\mathrm{Zn}(\mathrm{Cd}) \mathrm{S}-\mathrm{GeS}_{2}$ systems was constructed using $\mathrm{X}$-ray diffraction analysis at $670 \mathrm{~K}[10]$. $\mathrm{Cu}_{2} \mathrm{ZnSnS}_{4}$ in quaternary Group $\mathrm{I}_{2}-\mathrm{II}-\mathrm{IV}-\mathrm{VI}_{4}$ is obtained through indium of Group III being replaced by the $\mathrm{Zn}$ of Group II and Sn of Group IV in $\mathrm{CuInS}_{2}$ in the evolution [11-13]. The evolutionary relationship is shown in Figure 1.

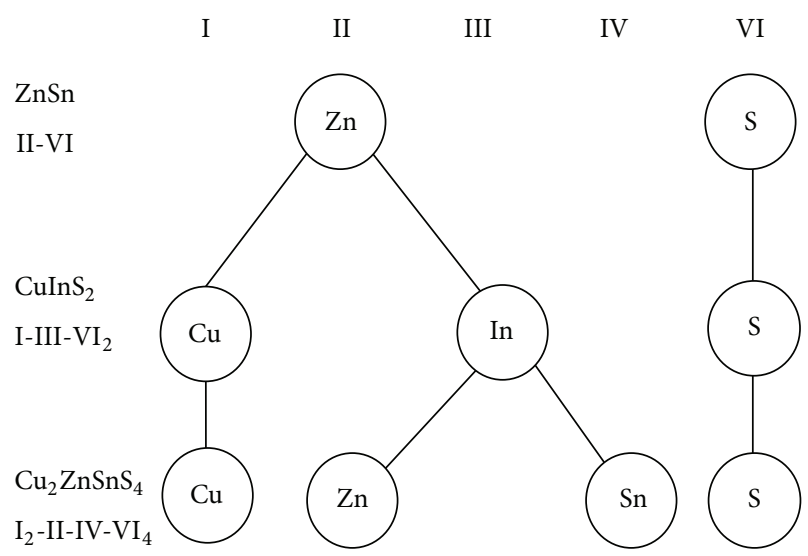

FIGURE 1: The evolution graph of quaternary CZTS (adapted from [12]).

$\mathrm{CuInS}_{2}$ and $\mathrm{Cu}_{2} \mathrm{ZnSnS}_{4}$ are just a representation of I-III-VI and $\mathrm{I}_{2}-\mathrm{II}-\mathrm{IV}-\mathrm{VI}_{4}$.

$\mathrm{Cu}_{2} \mathrm{ZnSnS}_{4}$ can be divided into two structures, stannite and kesterite, according to the different locations of $\mathrm{Cu}$ and $\mathrm{Zn}$, as shown in Figure 2. It can be seen that stannite evolves from (001) oriented $\mathrm{CuAu}$ and kesterite from (201) oriented Chalcopyrite [14]. In addition, people presented a PMCA-primitive-mixed $\mathrm{CuAu}$ structure in the theoretical simulations, and it was obtained by rotating the $\mathrm{ZnSn}$ layer in stannite 90 degrees. This structure currently had not yet been reported in the experiment [8].

There are still a lot of controversies about the structure of $\mathrm{Cu}_{2} \mathrm{ZnSnS}_{4}$. First principles proved that $\mathrm{I}_{2}-\mathrm{II}-\mathrm{IV}-\mathrm{VI}_{4}$ compounds are the most stable in kesterite, while Olekseyuk et al. found that the monocrystal $\mathrm{Cu}_{2} \mathrm{ZnSnSe}_{4}$ was of the stannite structure [16]. Nateprov et al. had determined the crystal structure of $\mathrm{Cu}_{2} \mathrm{ZnSnSe}_{4}$ using the single crystal $\mathrm{X}$-ray diffraction and found that the best refinement was obtained for the model in the space group $I-42 \mathrm{~m}$, which suggested that cooper and zinc atoms alternate in the $d$ Wickoff position of the space group and statistically occupy it with equal probability [17]. Schorr et al. observed the partial disorder of $\mathrm{Zn}$ and $\mathrm{Cu}$ produced by $\mathrm{CuZn}$ layer in kesterite structure through neutron scattering [18]. CuZn layer partial disordering made kesterite structure exhibit the same space group with stannite. It was more difficult for X-ray diffraction spectroscopy to distinguish the two structures. Schorr had proved that $\mathrm{Cu}_{2} \mathrm{ZnSnS}_{4}$ was of the kesterite structure by neutron scattering and Rietveld analysis [19]. Persson proposed that its structure could be judged by utilizing the anisotropy of stannite and kesterite to measure the dielectric constant of parallel to axis $c$ and perpendicular to the axis $c[20]$.

People have made a lot of researches on the lattice constants of $\mathrm{Cu}_{2} \mathrm{ZnSnS}_{4}$ by $\mathrm{X}$-ray diffraction and neutron scattering. As shown in Table 1, the theoretical calculations also showed that the lattice constant of sulfide is less than that of selenide. There are still some differences between stannite and kesterite, but there is no unified conclusion till today. 


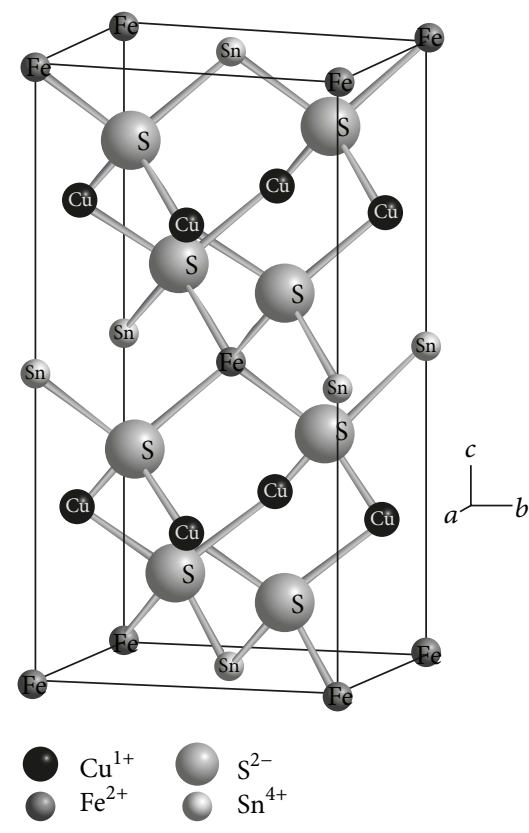

(a)

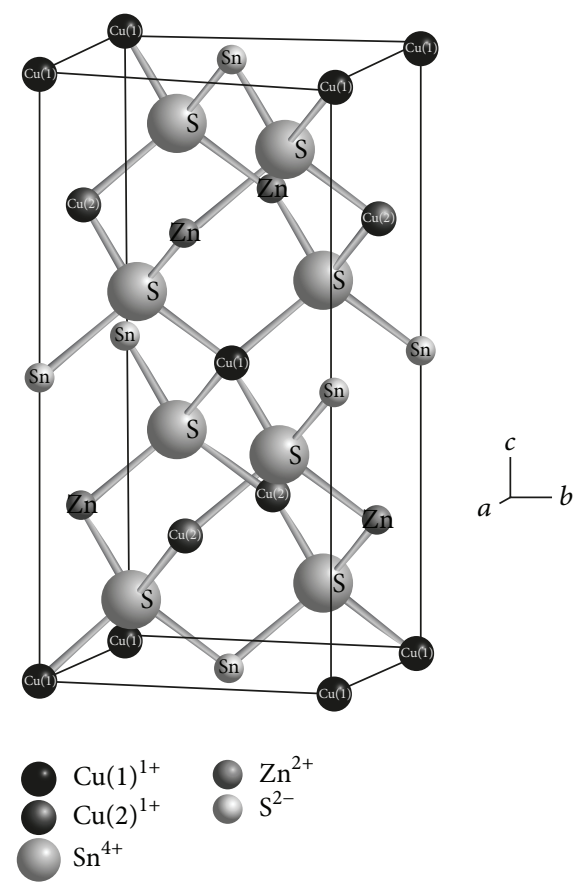

(b)

FIGURE 2: Crystal structures of (a) stannite and (b) kesterite (modified from [3, 15]).

TABLE 1: Lattice constants and band gap of $\mathrm{Cu}_{2} \mathrm{ZnSnS}_{4}$ and $\mathrm{Cu}_{2} \mathrm{ZnSnSe}_{4}$.

\begin{tabular}{lcccc}
\hline & $a / \AA$ & $b / \AA$ & $c / 2 a$ & $E_{g} / \mathrm{eV}$ \\
\hline Sulphide & 5.419 & 10.854 & 1.0015 & 1.5 \\
Selenide & 5.695 & 11.345 & 0.9960 & 1.0 \\
\hline
\end{tabular}

TABLE 2: Theoretical calculating value of the band gap of $\mathrm{Cu}_{2} \mathrm{ZnSnS}_{4}$ and $\mathrm{Cu}_{2} \mathrm{ZnSnSe}_{4}$.

\begin{tabular}{lcccc}
\hline & $\begin{array}{c}\text { Chen } \\
\text { et al. [11] }\end{array}$ & Vidal et al. [21] & $\begin{array}{c}\text { Paier } \\
\text { et al. [22] }\end{array}$ & Persson [20] \\
\hline Se kesterite & 0.96 & 1.02 & & 1.05 \\
Se stannite & 0.82 & 0.87 & & 0.89 \\
S kesterite & 1.50 & 1.64 & 1.49 & 1.56 \\
S stannite & 1.38 & 1.33 & 1.30 & 1.42 \\
\hline
\end{tabular}

2.1.2. Energy Band Structure of CZTS. The uncertainty of basic composition and crystal structure leads to the research difficulties of electrical, optical properties, and so on. For the solar cell materials, electrical properties, such as width of energy band, density of states, doping behavior, and transport properties, are very important. For the energy gap of $\mathrm{Cu}_{2} \mathrm{ZnSnS}_{4}$ and $\mathrm{Cu}_{2} \mathrm{ZnSnSe}_{4}$, although there are some nuances in a lot of theoretical results, they all reflect that the band gap of sulfide is wider than that of selenide, as shown in Table 2.

For CZTS doped with selenium, if the proportion of Se in Se and $S$ is recorded as $X$, it may be represented as

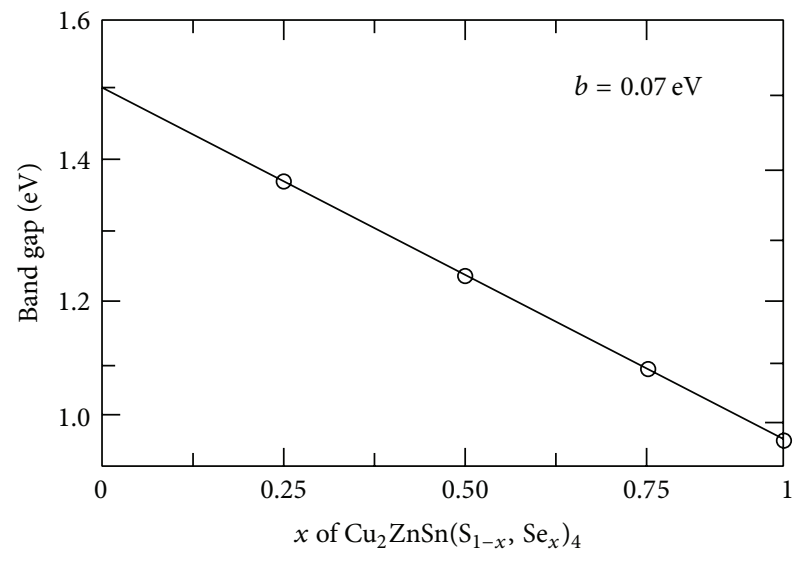

FIGURE 3: Varying diagram of $\mathrm{Cu}_{2} \mathrm{ZnSn}\left(\mathrm{S}_{1-x}, \mathrm{Se}_{x}\right)_{4}$ band gap with $x$ (adapted from [23]).

$\mathrm{Cu}_{2} \mathrm{ZnSn}\left(\mathrm{S}_{1-x}, \mathrm{Se}_{x}\right)_{4}$, and its band gap can be adjusted from $1.0 \mathrm{eV}$ to $1.5 \mathrm{eV}$ :

$$
E_{g}(X)=(1-x) E_{g}(\mathrm{CZTS})+x E_{g}(\mathrm{CZTSe})-b x(l-x) .
$$

When $b$ is equal to 0.07 , we can obtain the varying diagram of band gap of $\mathrm{Cu}_{2} \mathrm{ZnSn}\left(\mathrm{S}_{1-x}, \mathrm{Se}_{x}\right)_{4}$ with $x$, as shown in Figure 3.

2.1.3. Research into Phase of CZTS. The addition of elements has increased the degrees of freedom of chemical composition and structure. The researches for quaternary 
semiconductor are more complex relative to the unary, binary simple semiconductors. When synthesizing quaternary semiconductor, it is noteworthy how to obtain quaternary semiconductor with specific composition and avoid the generation of binary, ternary impurity phase. $\mathrm{Cu}_{2} \mathrm{ZnSnS}_{4}$ contains four kinds of elements, which can be combined to form many other binary, ternary compounds such as $\mathrm{CuS}, \mathrm{Cu} 2 \mathrm{~S}, \mathrm{ZnS}, \mathrm{SnS}, \mathrm{SnS}_{2}$, and $\mathrm{Cu}_{2} \mathrm{SnS}_{3}$. In the process of synthesizing $\mathrm{Cu}_{2} \mathrm{ZnSnS}_{4}$, when the composition proportion of some uncertain elements shows higher or the growth environment changes, these heterocyclic compounds will be generated.

At present, there is no clear idea about the growth mechanism of $\mathrm{Cu}_{2} \mathrm{ZnSnS}_{4}$. It is found very difficult to fabricate single-phase $\mathrm{Cu}_{2} \mathrm{ZnSnS}_{4}$ in the experiment. Olekseyuk et al. had studied the phase equilibrium of $\mathrm{Cu}_{2} \mathrm{~S}-\mathrm{ZnS}-\mathrm{SnS}_{2}$ system in the earlier time [24], and Dudchak and Piskach also studied the phase equilibrium of $\mathrm{Cu}_{2} \mathrm{SnSe}_{3}-\mathrm{SnSe}_{2}-\mathrm{ZnSe}$ [25] and found that single-phase stannite $\mathrm{Cu}_{2} \mathrm{ZnSnS}_{4}$ or $\mathrm{Cu}_{2} \mathrm{ZnSnSe}_{4}$ exists only in a very small field; the tolerability of component deviation was only $1 \%-2 \%$ below $550^{\circ} \mathrm{C}$, which was far less than the tolerability range of chalcopyrite to $\mathrm{Cu}$-poor, which is $4 \%$. In addition, Olekseyuk had investigated the phase equilibrium in the quazythird-timed system $\mathrm{Cu}_{2} \mathrm{Se}-$ $\mathrm{ZnSe}-\mathrm{Cu}_{2} \mathrm{SnSe}_{3}$ and found that the quaternary compound $\mathrm{Cu}_{2} \mathrm{ZnSnSe}_{4}$, which melted incongruently at $1061 \mathrm{~K}$, was formed in the system. The compound crystallized in the tetragonal structure with the lattice parameters $a=0,5855 \mathrm{~nm}$ and $c=1,1379 \mathrm{~nm}$ [26].

Nagoya et al. has introduced the element chemical potential $U_{x}$ to describe the element content in artificial atmosphere. $\mathrm{U}_{x}=0$ indicates that the element content is higher and pure elemental material can be formed. The lower $\mathrm{U}_{x}$ is, the less element composition is. Therefore, in order to avoid the simple substance of residual constituent elements in the synthetic sample, we require that $\mathrm{U}_{x}<0$. In $\mathrm{Cu}$-rich condition $\left(\Delta \mathrm{U}_{\mathrm{Cu}}=0\right)$, it can get the phase boundary of CZTS $\mathrm{ZnS}, \mathrm{SnS}, \mathrm{CuS}$, and $\mathrm{Cu}_{2} \mathrm{SnS}_{3}$ through different combinations of $\Delta \mathrm{U}_{\mathrm{Sn}}$ and $\Delta \mathrm{U}_{\mathrm{s}}[27,28]$.

As shown in Figure 4, the scope of chemical potential which is in favour of synthesizing quaternary semiconductor phase of $\mathrm{Cu}_{2} \mathrm{ZnSnS}_{4}$ is very narrow. Stable region is only $1 \mathrm{eV}$ long and $0.1 \mathrm{eV}$ wide. At present, the maximum efficiency of $\mathrm{Cu}_{2} \mathrm{ZnSnS}_{4}$ solar cells is obtained in $\mathrm{Zn}$-rich and $\mathrm{Cu}$-poor material, $\mathrm{Cu} /(\mathrm{Zn}+\mathrm{Sn})=0.8, \mathrm{Zn} / \mathrm{Sn}=1.22$, and for viewing the statistics of different components cells efficiency, the cells tending to deviate the requirement have a low efficiency [29]. Nagoya et al. calculated the chemical potential phase diagram of $\mathrm{Cu}_{2} \mathrm{ZnSnS}_{4}$ in the $\mathrm{Cu}$-poor condition and found that the stable regions of $\mathrm{Cu}_{2} \mathrm{ZnSnS}_{4}$ were smaller than the those of the $\mathrm{Cu}$-rich [27]. From the phase diagrams of Figure 4 and the theoretical calculation, it can be seen that $\mathrm{ZnS}$ impurity phase is likely to exist in the $\mathrm{Cu}_{2} \mathrm{ZnSnS}_{4}$ material of $\mathrm{Zn}$-rich and $\mathrm{Cu}$-poor. At least, the fact that there is $\mathrm{ZnSe}$ in the thin film materials of $\mathrm{Cu}_{2} \mathrm{ZnSnSe}_{4}$ has been already confirmed by SIMS and the means of AES depth analysing in the Lab [30-32]. The $\mathrm{Cu}_{2} \mathrm{SnS}_{3}$ band gap is smaller than CZTS, only with $1.0 \mathrm{eV}$ [33], which will reduce the open-circuit voltage of cells. In addition, CZTS also has a high temperature phase

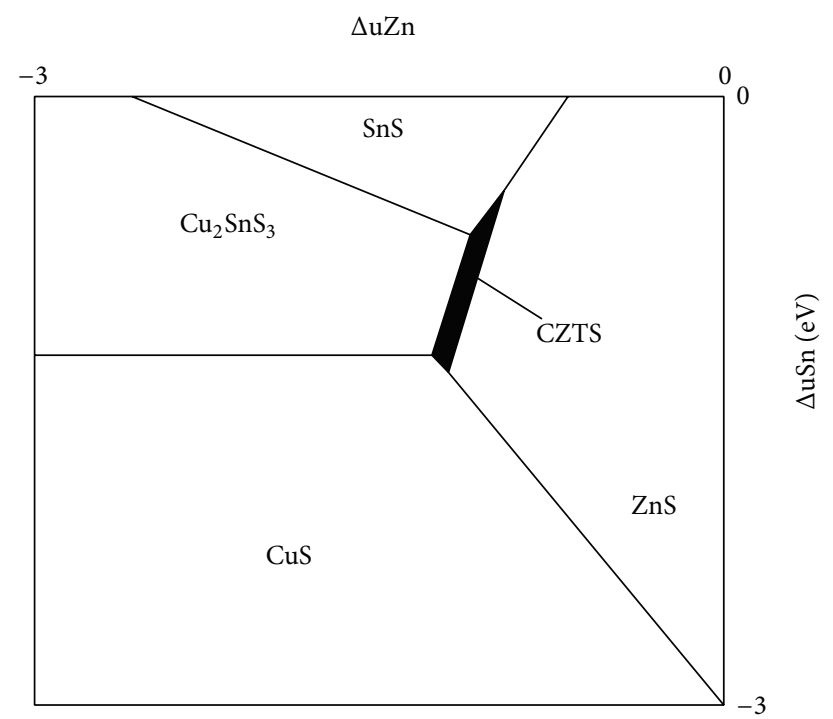

FIgUre 4: The chemical potential phase diagram of $\mathrm{Cu}_{2} \mathrm{ZnSnS}_{4}$ under $\mathrm{Cu}$-rich conditions (adapted from [27]).

transition similar to $\mathrm{CuInSe}_{2}$, and $\mathrm{CuInSe}_{2}$ will transit from tetragonal chalcopyrite to cubic sphalerite structure at $806^{\circ} \mathrm{C}$ $[13,34,35]$, which is similar to the inversion of $\mathrm{Cu}-\mathrm{In}$ cation. The structure of CZTS will transit from tetragonal kesterite to cubic sphalerite [36] at $876^{\circ} \mathrm{C}$ due to the inversion of $\mathrm{Cu}_{\mathrm{Sn}}$ and $\mathrm{Zn}_{\mathrm{Sn}}$.

\subsection{Preparation Method of CZTS Thin Film}

2.2.1. Electrochemical Deposition Method. Electrochemical deposition is a coating method to reduce the cations in the aqueous solution, organic solution, or hot-dip fluid in the cathode by supplying potential difference with external circuit power. In the 1970 s, people began to try the electrochemical deposition of semiconductor materials [37, 38].

Nowadays, the electrodeposition technique has been widely employed in the fabrication of solar cells, such as the CIGS solar cells researched by France CISEL [39] and the CdTe cells produced by BP plc. [40]. Although CdS in the electrodeposition had used the thiourea as precursors [41], it was very difficult to find such a stable sulfur source in the electrodeposition CZTS. In 2008, the Bath University in Britain employed the method of laminating and vulcanizing electrodeposition $\mathrm{Cu} / \mathrm{Sn} / \mathrm{Zn}$ to obtain the CZTS solar cells with a conversion efficiency of $0.8 \%$ [42-44]. In 2010, by annealing for 2 hours at $575^{\circ} \mathrm{C}$ in an atmosphere of $\mathrm{N}_{2}$ carrier gas containing S powder and $10 \% \mathrm{H}_{2}$, they obtained the cells device with a conversion efficiency of $3.2 \%$ through improved technology [45].

In 2009, Nagaoka University of Technology obtained a conversion efficiency of $0.98 \%$ by using electrodeposition of $\mathrm{Cu} / \mathrm{Sn} / \mathrm{Zn}$ laminate and then annealing it for 2 hours at $600^{\circ} \mathrm{C}$ in the carrier gas containing sulfur powder. Before electrodeposition, they plated a $\mathrm{Pb}$ layer on the Mo to increase the adhesion of substrate [46]. Later, they gained the solar 
cells with a conversion efficiency of 3.16\% through the onestep codeposited CuZnSn alloy and then annealing for 2 hours at $600^{\circ} \mathrm{C}$ in the carrier gas containing sulfur powder [47].

In the same year, Ennaoui in Germany HZB obtained the CZTS solar cells with a photovoltaic conversion efficiency of $3.4 \%$ through one-step codeposition CuZnSn in the solution containing $3 \mathrm{mM} \mathrm{Cu}^{2+}, 3 \mathrm{mM} \mathrm{Zn}^{2+}, 30 \mathrm{mM} \mathrm{Sn}^{2+}$, and some complexing agent and then annealing it for 2 hours at $550^{\circ} \mathrm{C}$ in an atmosphere of $\mathrm{Ar}$ gas containing $5 \% \mathrm{H}_{2} \mathrm{~S}$ and then made CZTS films with Cu-poor etching the $\mathrm{Cu}_{x} \mathrm{~S}$ in the KCN solution with $3.5 \%$ density. After light treatment for 10 minutes, its efficiency was increased to $3.6 \%[48,49]$.

In 2012, IBM utilized the commercially plating solution to sequentially deposit $\mathrm{Cu} / \mathrm{Zn} / \mathrm{Sn}$ laminate and annealed it for 30 minutes in $\mathrm{N}_{2}$ at $350^{\circ} \mathrm{C}$, made CuZnSn alloying, and then annealed for 12 minutes at $585^{\circ} \mathrm{C}$ in the $\mathrm{N}_{2}$ containing sulfur powder and finally deposited $\mathrm{CdS}$ and $\mathrm{ZnO}$ to obtain the CZTS solar cells with an efficiency of 7.3\% [50].

More recently, Shinde et al. [51] reported a novel chemical successive ionic layer adsorption and reaction (SILAR) technique for CZTS thin films formation by sequential reaction on SLG substrate surface. CZTS thin films were formed by sequential immersion of the substrate into the beakers containing the cationic precursor solutions of $0.1 \mathrm{M}$ $\mathrm{CuSO}_{4}, 0.05 \mathrm{M} \mathrm{ZnSO}_{4}$, and $0.05 \mathrm{M} \mathrm{SnSO}_{4}(1: 1: 1)$ and the anionic precursor solution of $0.2 \mathrm{M}$ thioacetamide. The films obtained were then annealed at $400^{\circ} \mathrm{C}$ for $4 \mathrm{~h}$. The photoelectrochemical solar cell (PEC) cell was constructed using the annealed CZTS thin film and exhibited an efficiency of $0.12 \%$.

Mali et al. [52] reported fabrication of CZTS thin film based solar cells using similar approach obtained a conversion efficiency of $0.396 \%$. This low efficiency of the device was due to the high contact resistance, which was not reported by the authors. The same group of researchers later on improved the efficiency of CZTS thin films based solar cell using similar approach to $1.85 \%$ [53]. This is the highest efficiency so far obtained for CZTS thin film based solar cell using wet chemistry (SILAR) technique.

Recently, Washio et al. [54] reported a novel approach for CZTS thin film based solar cell using oxide precursors by an open atmosphere chemical vapour deposition (OACVD). CZTS thin films were prepared on SLG and Mo coated SLG substrates by the sulphurisation of oxide precursor thin films $(\mathrm{Cu}-\mathrm{Zn}-\mathrm{Sn}-\mathrm{O})$ in $\mathrm{N}_{2}+\mathrm{H}_{2} \mathrm{~S}(5 \%)$ atmosphere at $520-560^{\circ} \mathrm{C}$ for $3 \mathrm{~h}$. The best solar cell yielded an efficiency of $6.03 \%$.

The merits of thin film preparation by electrodeposition are deposition process with low temperature, no residual thermal stress between coating and substrate, and well interface bonding; the uniform thin film can be prepared on various surfaces in complex shapes and porous surface; coating thickness, chemical composition, structure and porosity can be precisely controlled, and simple equipment and low investment are other merits.

2.2.2. Vacuum Deposition Method. Vacuum deposition method is a physical deposition method that puts the film raw material into the vacuum chamber and heats it to high temperature to make the atoms or molecules escape from the surface then form a vapor stream entering the surface of the plated substrate; due to the low temperature of substrate, it condenses to form a solid film.

In 1997, Katagiri in Nagaoka University of Technology utilized the electron beam evaporation to fabricate the $\mathrm{Cu}_{2} \mathrm{ZnSnS}_{4}$ thin film solar cells with an efficiency of $0.66 \%$ for the first time $[8,9]$. Later, through improving technology with employing $\mathrm{ZnS}$ as evaporation source, they obtained the photoelectric conversion efficiency of $2.62 \%$ in 2001 [55]. In 2003, through adding $\mathrm{NaS}$ and improving the vacuum background of annealing with a stainless steel chamber, they and obtained an efficiency of 5.45\% [56].

In 1998, ZSW Company of Germany cooperated with Germany Stuttgart University and obtained the CZTS solar cells with efficiency of $2.3 \%$ by coevaporation method [57, 58]. ZSW is currently the record-holder of CIGS solar cell with an efficiency of $20.3 \%$ [59]. When employing the quaternary coevaporation method of $\mathrm{Cu}, \mathrm{ZnS}, \mathrm{SnS}_{2}$, and $\mathrm{S}$, Weber et al. found that the temperature of substrate is at 300 $600^{\circ} \mathrm{C}$; once the substrate temperature was above $400^{\circ} \mathrm{C}, \mathrm{Sn}$ would have a severe loss [60] and it was difficult to control the process.

In 2009, Schock turned from ZSW Company of Germany to Germany HZB (Helmholtz-Zentrum Berlin) to continue the research of CZTS coevaporation. HZB had obtained more than $10 \%$ efficiency in preparing large-area $(125 \mathrm{~cm} * 65 \mathrm{~cm})$ $\mathrm{Cu}(\mathrm{In}, \mathrm{Ga}) \mathrm{S}_{2}$ module by magnetron sputtering and made many researches in the na-doped, Ga gradient distribution and surface defects and other aspects [61-68]; meanwhile, they also made some researches about the preparation technology of electrochemical deposition and magnetron sputtering in CZTS aspects as well as KCN impacting on the band offset [14, 69-73]. Schubert et al. and Bär et al. obtained $\mathrm{Cu}$-rich CZTS by using quaternary coevaporation $\mathrm{ZnS}, \mathrm{Cu}$, $\mathrm{Sn}$, and $\mathrm{S}$ technology and then removed the impurity phase of $\mathrm{Cu}_{x} \mathrm{~S}$ by $\mathrm{KCN}$ and had obtained the conversion efficiency of $4.1 \%[73,74]$.

In 2010, IBM obtained the CZTS solar cell with an efficiency of $6.8 \%$ by coevaporation [75]. In 2011, they further improved equipment and craft, employing the $\mathrm{Cu}, \mathrm{Zn}$, and Sn evaporation source of Knudsen type and Veeco $S$ source box in metal tantalum with valves; the substrate temperature increased from $110^{\circ} \mathrm{C}$ to $150^{\circ} \mathrm{C}$, and the annealing temperature increased from $540^{\circ} \mathrm{C}$ to $570^{\circ} \mathrm{C}$; the annealing time was also 5 minutes. Although the film was only $600 \mathrm{~nm}$, they still obtained the CZTS solar cells with an efficiency of $8.4 \%$, which is currently the highest CZTS cells efficiency without Se [76].

Saga University of Japan [77] also carried out some researches on the vacuum deposition preparing CZTS film, but there were no reports related devices. In addition, Moriya et al. from Nagaoka University of Technology employed pulsed laser deposition (PLD) sputtering from the quaternary CZTS targets to fabricate CZTS solar cells and obtained a conversion efficiency of $1.7 \%$; the CZTS target was made of incurring $\mathrm{Cu}_{2} \mathrm{~S}, \mathrm{ZnS}$, and $\mathrm{SnS}_{2}$ powder into targets before annealing for 24 hours at $750^{\circ} \mathrm{C}$ under vacuum $[78,79]$. 
CZTS films prepared by vacuum evaporation method are simple in principle and better in quality. However, it is difficult to control the ratio of element chemistry, thus the yield is lower. In addition, the preparation method of vacuum deposition wastes film materials, and the cost is relatively high.

\subsubsection{Electron Beam Evaporation Method. Electron beam} evaporation method is to employ electric field to make electron getting kinetic energy to bombard the evaporation material of anode, which can make the material vaporize to achieve evaporation coating.

In 1996, Nagaoka National College of Technology Research Group utilized the electron beam evaporation and curing method to fabricate the solar cells of $\mathrm{ZnO}: \mathrm{Al} / \mathrm{CdS} /$ CZTS/Mo/SLG structure with the open circuit voltage of $400 \mathrm{mV}$, short circuit current of $6.0 \mathrm{~mA} / \mathrm{cm}^{2}$, and fill factor of 0.277 , and the conversion efficiency was only $0.66 \%$. In order to improve the conversion efficiency, Hironori and Katagiri et al. employed $\mathrm{Cu}, \mathrm{Sn}$ ( or $\mathrm{SnS}_{2}$ ), and $\mathrm{ZnS}$ as vapor deposition material by electron beam evaporation method, changing the order of deposition from an evaporation to multiple cycles evaporation, using soda lime glass instead of the ordinary glass, using $\mathrm{ZnO}: \mathrm{Al}$ instead of $\mathrm{ZnO}$ as a window layer, and finally the cells efficiency was increased to $5.45 \%$ [80].

Electron beam evaporation method overcomes many defects of the resistance heating evaporation, especially suitable for the production of high-melting point material and high purity thin film material. At present, preparation of the CZTS thin film with electron beam evaporation method is the most widely study in the laboratory, and the surface morphology, phase matching, and optical performance of thin film are better.

\subsubsection{Magnetron Sputtering Method. Magnetron sputtering} is that the electrons crash with Ar atom in the electric field with ionizing abundant argon ions and electrons, and the electrons fly to the substrate. The Ar ions are accelerated in the electric field to bombard the target with sputtering a lot of target atoms, and the neutral target atoms (or molecules) are deposited on the substrate to form film.

In 1988, Ito and Nakazawa in Shinshu University of Japan utilized the sputtering method to fabricate the CZTS for the first time. They sputtered the CZTS film from target material by employing the method of atomic beam sputtering and obtained the CZTS film with optical band gap of $1.45 \mathrm{eV}$ and hole mobility of $1 \mathrm{~cm}^{2} /$ V.S. After forming a heterojunction with $\mathrm{CdZnO}$, they obtained the solar cells with open-circuit voltage of $165 \mathrm{mV}$ [11]. In 2011, Ito in Shinshu University and Momose in Japan Nagano National College of Technology studied the method of sputtering $\mathrm{Cu}-\mathrm{Sn}-\mathrm{Zn}$ metal precursor and then vulcanized to fabricate CZTS and obtained the CZTS cells with an efficiency of 3.7\% [81].

In 2007, Nagaoka University of Technology in Japan, after having successfully fabricated the CZTS solar cells with an efficiency of $5.45 \%$ by electron beam evaporation, had successfully obtained the CZTS cells with an efficiency of $5.74 \%$ by RF sputtering [82]. Experimental procedure was to sputter $\mathrm{Cu}, \mathrm{ZnS}$, and $\mathrm{SnS}$ firstly, then anneal in an atmosphere of $\mathrm{N}_{2}$ gas containing $20 \% \mathrm{H}_{2} \mathrm{~S}$ for three hours at $580^{\circ} \mathrm{C}$, finally obtain the CZTS thin film of Zn-rich and $\mathrm{Cu}$-poor. Later the CZTS thin film was immersed in deionized water for 10 minutes, which removed the metal oxides of surface and further increased the cells efficiency to $6.77 \%$ [83].

In 2010, Salome and Femandes et al. in University of Aveiro, Portugal cooperated with Germany HZB to fabricate the CZTS solar cells with conversion efficiencies of $0.68 \%$ by utilizing the sputtering $\mathrm{Zn} / \mathrm{Sn} / \mathrm{Cu}$ and annealing with $\mathrm{S}$ powder for 10 minutes at $525^{\circ} \mathrm{C}$ under the $\mathrm{N}_{2}$ carrier gas. Katagiri et al. in Japan fabricated the CZTS thin film solar cells with the highest photoelectric conversion efficiency of $6.8 \%$ by vacuum sputtering.

Muhunthan et al. [84] performed study on cosputtering from the metal targets and sulfurization in ambient $\mathrm{H}_{2} \mathrm{~S}$ for the first time. He used metal targets to help in controlling the composition of the film.

Khalkar et al. [85] studied the formation and properties of CZTS thin films deposited using cosputtering from the $\mathrm{Cu}, \mathrm{SnS}$, and $\mathrm{ZnS}$ targets. The effect of working pressure, target power, and annealing conditions were also studied. The optimized parameters were applied for the deposition of CZTS thin film and films were used for postannealing.

Compared with the conventional vacuum deposition, sputter coating has many merits, such as precisely controlling the stoichiometry of elements, obtaining the film with high density, full use of raw materials, freely choosing the deposition site, reducing the contamination for vacuum chamber, the higher uniformity degree of film, and suitability for the preparation of larger scale CZTS thin film solar cells. It is now one of the most promising methods to prepare CZTS thin film.

However, there are also some shortcomings for balanced magnetron sputtering. Due to the effect of electric field, the effective coating area is shorter, which limits the geometry dimension of the work pieces to be coated. It is not suitable for larger parts or installed furnace capacity; in the balanced magnetron sputtering, the energy of flying target ion is lower, and the migration rate of low-energy deposited atoms on the substrate surface is low, so it is easy to produce a porous coarse columnar structure film. The appearance of unbalanced magnetron sputtering has partly overcome the shortcomings above, which leads the plasma on the cathode target surface to the range of $200-300 \mathrm{~mm}$ in front of sputtering target, so that the substrate can immerse in the plasma, which greatly improves the quality of the film.

2.2.5. Spray Pyrolysis Method. Spray pyrolysis method is to heat the surface of substrate to about $600^{\circ} \mathrm{C}$ and then spray one or more metal salt solutions onto the substrate surface; high temperature will cause pyrolysis of the spray coating, which will form a coat on substrate surface. The quality and performance of thin film fabricated by spray pyrolysis relate to substrate temperature. If the substrate temperature is too high, it will be uneasy for the film to be adsorbed on the substrate; when the substrate temperature is too low, the crystallization of film will be deteriorated. According to 
experiment results, the CZTS thin film will have better optical property if the substrate temperature is controlled within the range of $500^{\circ} \mathrm{C}-650^{\circ} \mathrm{C}$ in pyrolysis.

Kamoun made a reaction in $\mathrm{CuCl}_{2}, \mathrm{ZnCl}_{2}$, and $\mathrm{SnCl}_{2}$ and vulcanized them in $\mathrm{SC}\left(\mathrm{NH}_{2}\right)_{2}$ solution by spray pyrolysis method. The substances reacted for 1 hour at the substrate temperature of $340^{\circ} \mathrm{C}$ and were annealed for 120 minutes at $550^{\circ} \mathrm{C}$. Finally, the CZTS thin films with a band gap of $1.5 \mathrm{eV}$ were fabricated. The spray pyrolysis device is simple and easy to operate; the experimental procedure is simple, and no vacuum and gas protection devices are needed, so the cost is low, and the thin-film materials have good performance [86].

2.2.6. Pulsed Laser Deposition Method. Pulsed laser deposition method is a physical vacuum deposition process that makes the high-power pulsed laser focuse on the target surface to produce high temperature and cauterization and then produce high pressure and high temperature plasma; the plasma emission expands in directional local area and deposits the substrate to form a thin film.

Moholkar et al. obtained the $\mathrm{Cu}_{2} \mathrm{~S}, \mathrm{ZnS}$, and $\mathrm{SnS}_{2}$ powder by grinding method, and the powder is made to CZTS target through the solid state reaction; they used an excimer laser beam to bombard the target, and CZTS thin film was deposited in a vacuum chamber, followed by annealing in $\mathrm{N}_{2}+\mathrm{H}_{2} \mathrm{~S}$ gas environment. The thin film cells based on this method have open circuit voltage of $585 \mathrm{mV}$, shortcircuit current density of $6.74 \mathrm{~mA} / \mathrm{cm}^{2}$ and fill factor of 0.51 , conversion efficiency of $2.02 \%$, and band gap of $1.52 \mathrm{eV}$. The study found that when the laser pulse frequency was in the range of $2-10 \mathrm{~Hz}$, the grain size increased with the increase of pulse frequency. Due to the high energy density of the laser and the effect of enhanced crystallization, we obtained uniform, single, and dense crystal grains [87].

Compared with other methods, this process is simple and it can deposit the film with ideal stoichiometric ratio through controlling the composition of ceramic target and the oxygen pressure, especially suitable for depositing the metal oxide thin films and multicomponent heteroepitaxial films. Furthermore, due to the bombardment of high energy laser beam, the atoms or molecules which are sputtered by target have high energy, which contributes to the deposition of high quality thin films at low temperature.

2.2.7. Sol-Gel Method. Sol-gel method is to make the readily hydrolyzable metal compound (inorganic salts or alkoxides) react with water in certain solvents, forming Sol through the process of hydrolysis and polycondensation and make Sol form liquid film on substrate by dipping or spin-coating method; after gelatinnization, it can be transformed into amorphous form (or crystalline) films by heat treatment.

Thin film fabricated by spin-coating method usually involves in three steps: first, preparing precursor solution containing specific ion; second, spin-coating precursor solution on the glass substrate to form film; and third, annealing thin films in a proper atmosphere.

In 2007, Tanaka et al. in Nagaoka University of Technology used the dimethyl alcohol as solvent and the ethanolamine as stabilizer to make sol gelatin with cupric acetate, zinc acetate, and tin chloride and coated it on the Mo glass. In order to obtain the appropriate thickness, spin coating needed to be repeated for 5 times and then they burned it at $300^{\circ} \mathrm{C}$ for 5 minutes in the air and annealed it at $500^{\circ} \mathrm{C}$ for 1 hour in an atmosphere of $\mathrm{N}_{2}$ gas containing $5 \% \mathrm{H}_{2} \mathrm{~S}$ again. Finally, they obtained the CZTS thin film with better component and the crystallinity [84]. In 2009, through improving the technology, firstly, spin-coat and dry the $0.35 \mathrm{M}$ sol for three times; then, spin-coat and dry the $1.76 \mathrm{M}$ sol for 5 times; finally obtain the CZTS film with uniform surface and the efficiency of $1.01 \%$ [88]. In 2011, they obtained a conversion efficiency of $2.03 \%$ by optimizing film components [89].

In 2009, Guo et al. in Purdue University fabricated the $16 \mathrm{~nm}$ CZTS nanoparticles by a hot infusion method, prepared the CZTS films by dropping coating method, and obtained the conversion efficiency of $0.8 \%$ [49]. In 2010, they obtained a conversion efficiency of $7.2 \%$ by knife coating [90], and the cells had no significant recession after lighting for a month.

In 2010, IBM obtained a conversion efficiency of $9.6 \%$ by spin-coating the hydrazine solution [91], which were the highest CZTS cells at that time [92, 93]. After adding the $\mathrm{MgF}_{2}$ antireflection layer, the conversion efficiency reached $10.1 \%$ [94].

Compared with other methods, it has many unique advantages: simple process equipment and without vacuum conditions or expensive equipment; large area of thin films can be prepared on substrate with different shapes and different materials. It is easy to obtain homogeneous and multicomponent oxide film and has easily quantitative doping; the film composition and microstructure can be effectively controlled. But there are also some problems: the price of raw materials is high, and some raw materials are organic, which is harmful to health; usually, the entire process requires a longer time (mainly referring to the aging time); there is a large number of micro-gel holes in the gelatin, a lot of gas and organics will escape from the drying process and lead to contraction.

\section{Results and Discussion}

Since the CZTS film is a kind of multicompound semiconductor which needs high demands in the accurate atomic ratio and the process conditions of lattice matching, the process has poor reproducibility and the yield of high efficient cells is low. Meanwhile, the crystalline state and the basic characteristics of the CZTS film have not been clearly figured and the relationship between material properties and device performance of CZTS cannot be accurately explained [95]. All these factors have increased the industrialization costs of CZTS solar cells and limited the long-term development of CZTS solar cells.

At present, most preparation methods of CZTS are in fabricating alloy precursor under the conditions of heating or high temperature then heating and vulcanizing in a sulfur source environment. Quaternary compounds film can be 
directly synthesized by one-step at room temperature, which eliminates the vulcanizing process so that it greatly reduces the complexity of production process. Meanwhile, it also reduces the carbon emission, which is a manufacturing process that is environmentally friendly. Physical deposition methods require a vacuum device, which makes the system more complex and production costs higher. The device structure of electrochemical method is simpler, to a large extent, and cost saving, and the electrochemical deposition is also a safe, controllable, energy-saving and environmentfriendly preparation technology, with low cost and easy operation. Therefore, deposition of the CZTS thin film solar cells directly by electrochemical method under the normal temperature is a promising material preparation technique [96].

Experiment shows that it will produce secondary species in the manufacturing process of CZTS thin film, such as metal sulfide and intermetallic compound. The secondary species in thin film will become the impurity scattering electrons that will reduce the degree of freedom of the electron and seriously affect the performance of thin film. The grain size also affects the performance of films. The smaller the grain is, the more the grains per unit area are, and the more the grain boundaries are. However, the grain boundaries are the recombination centers, which will reduce the minority carrier lifetime and drift length. CZTS thin film will have cracks after annealing. Although the number of cracks can be reduced by adding polymer adhesive, it will indirectly bring in the carbon impurities, and the gap between the CZTS film and the substrate will increase the resistivity. It will also cause the tin gasifing in the annealing and sulfide process and the place where the film in contact with the substrate is vulcanized uniformly and insufficiently. Judged from the electrical properties, currently, due to the lower shunt resistance, the short circuit current density of CZTS thin film prepared is lower. The ideal cell requires a higher shunt resistance and a lower series resistance. Oxides will be introduced in the process of preparation of CZTS films, which increases the resistance of thin layer, thereby increasing the series resistance. Further, the internal defects and impurities introduced during manufacture also significantly affect the electrical properties of the films. In addition to above problems, the certain drugs used are highly toxic, explosive, and flammable chemicals and require a harsh environment for transport and storage, which increases the cost of industrial production.

\section{Conclusions}

In the field of CZTS films, Mitzi et al. in IBM have fabricated the CuZnSnSSe thin film solar cells with the photoelectric conversion efficiency of $9.66 \%$ by using thin film deposition method-based on solution particle. It is currently the highest conversion efficiency using the preparation vacuum method. At present, people in China have carried out the simulation of CZTS materials structure and material preparation. In 2010, Shanghai Jiaotong University fabricated the CZTS thin film solar cells by grinding printing method. Although the conversion efficiency was only $0.49 \%$, it had the merits of low cost, simple operation, and suitability for the preparation of large area thin film field emission cathode. Therefore, it is a promising method in the future. CZTS thin film solar cells have become the hot spot of thin film solar cell research in recent year due to the unique features. But we have to say that no matter what methods we take, the conversion efficiency of CZTS thin film cells is not ideal, with the highest less than $12 \%$, a large gap between CZTS thin film cells and silicon solar cells, expensive manufacturing equipment, complex process steps, high cost, and low yield. Although the current efficiency of electrochemical deposition is general, the low cost is suitable for large-scale manufacturing. The efficiency of new CZTSSe thin-film cells is higher and it can be used as a substitute for CZTS thin films before technology in large-scale production for CZTS thin films is mature. However, the Se is a rare element and has a higher price. If the introduction of impurities and internal defects can be limited during the process of electrochemical deposition film and the chemical proportion in each element can be controlled effectively (Usually the ideal $\mathrm{Cu} /(\mathrm{zinc}+\mathrm{Sn})$ and zinc/Sn ratio of CZTS film is between 0.85 to 0.96 and 1.05 to 1.30 resp. [97]), meanwhile fabricating the crystal grain of large size, reducing the grain boundary, increasing the minority carrier lifetime and mean free path, the absorption layer meeting the requirements of the thin-film cells can be obtained. To achieve the above requirements, it is necessary for us to understand the formation mechanism of CZTS thoroughly.

In short, with the further development of the preparation technology and equipment, as well as the mature theoretical research about basic features and crystallization condition of CZTS thin film, with its environmentally friendly features, rich content in the earth crust, and good photoelectric performance, CZTS thin film will certainly become a promising photovoltaic material after the CIGS thin film.

\section{Conflict of Interests}

The authors declare that there is no conflict of interests regarding the publication of this paper.

\section{Acknowledgment}

The present study was supported by National International Cooperation Special Projects in Science and Technology, China (Grant no. 2011DFA62380).

\section{References}

[1] S. C. Riha, B. A. Parkinson, and A. L. Prieto, "Solution-based synthesis and characterization of $\mathrm{Cu}_{2} \mathrm{ZnSnS}_{4}$ nanocrystals," Journal of the American Chemical Society, vol. 131, no. 34, pp. 12054-12055, 2009.

[2] C. Steinhagen, M. G. Panthani, V. Akhavan, B. Goodfellow, B. Koo, and B. A. Korgel, "Synthesis of $\mathrm{Cu}_{2} \mathrm{ZnSnS}_{4}$ nanocrystals for use in low-cost photovoltaics," Journal of the American Chemical Society, vol. 131, no. 35, pp. 12554-12555, 2009. 
[3] S. R. Hall, J. T. Szymanski, and J. M. Stewart, "Kesterite $\mathrm{Cu}_{2}(\mathrm{Zn}, \mathrm{Fe}) \mathrm{SnS}_{4}$ and stannite $\mathrm{Cu}_{2}(\mathrm{Fe}, \mathrm{Zn}) \mathrm{SnS}_{4}$ structurally similar but distinct minerals," The Canadian Mineralogist, vol. 16, pp. 131-137, 1978.

[4] S. Wagner and P. M. Bridenbaugh, "Multicomponent tetrahedral compounds for solar cells," Journal of Crystal Growth, vol. 39, no. 1, pp. 151-159, 1977.

[5] K. Ito and T. Nakazawa, "Electrical and optical properties of stannite-type quaternary semiconductor thin films," Japanese Journal of Applied Physics, vol. 27, no. 11, pp. 2094-2097, 1988.

[6] H. Katagiri, M. Nishimura, T. Onozawa et al., "Rare-metal free thin film solar cell," in Proceedings of the Power Conversion Conference, vol. 2, pp. 1003-1006, 1997.

[7] H. Katagiri, N. Hando, S. Sasaguchi, S. Yokota, J. Hoshino, and T. Ohashi, "Preparation and evaluation of $\mathrm{Cu}_{2} \mathrm{ZnSnS}_{4}$ thin films by sulfurization of E-B evaporated precursors," Solar Energy Materials and Solar Cells, vol. 49, no. 1-4, pp. 407-414, 1997.

[8] B. R. Pamplin, "Super-cell structure of semiconductors," Nature, vol. 188 , no. 4745, pp. 136-137, 1960.

[9] W. Schäfer and R. Nitsche, "Tetrahedral quaternary chalcogenides of the type $\mathrm{Cu}_{2} \mathrm{IIIVS}_{4}\left(\mathrm{Se}_{4}\right)$," Materials Research Bulletin, vol. 9, no. 5, pp. 645-654, 1974.

[10] O. V. Parasyuk, L. V. Piskach, Y. E. Romanyuk, I. D. Olekseyuk, V. I. Zaremba, and V. I. Pekhnyo, "Phase relations in the quasibinary $\mathrm{Cu}_{2} \mathrm{GeS}_{3}-\mathrm{ZnS}$ and quasi-ternary $\mathrm{Cu}_{2} \mathrm{~S}-\mathrm{Zn}(\mathrm{Cd}) \mathrm{S}-\mathrm{GeS}_{2}$ systems and crystal structure of $\mathrm{Cu}_{2} \mathrm{ZnGeS}_{4}$," Journal of Alloys and Compounds, vol. 397, no. 1-2, pp. 85-94, 2005.

[11] S. Chen, A. Walsh, Y. Luo, J.-H. Yang, X. G. Gong, and S.$\mathrm{H}$. Wei, "Wurtzite-derived polytypes of kesterite and stannite quaternary chalcogenide semiconductors," Physical Review B, vol. 82, no. 19, Article ID 195203, 2010.

[12] A. Walsh, S. Chen, S. Wei, and X. Gong, "Kesterite thin-film solar cells: advances in materials modelling of $\mathrm{Cu}_{2} \mathrm{ZnSnS}_{4}$," Advanced Energy Materials, vol. 2, pp. 400-409, 2012.

[13] S. Schorr, "Structural aspects of adamantine like multinary chalcogenides," Thin Solid Films, vol. 515, no. 15, pp. 5985-5991, 2007.

[14] A. Ennaoui, M. Lux-Steiner, A. Weber et al., " $\mathrm{Cu}_{2} \mathrm{ZnSnS}_{4}$ thin film solar cellsfrom electroplated precursors: novel low-cost perspective," Thin Solid Films, vol. 517, no. 7, pp. 2511-2514, 2009.

[15] G. P. Bernardini, D. Borrini, A. Caneschi et al., "EPR and SQUID magnetometry study of $\mathrm{Cu}_{2} \mathrm{FeSnS}_{4}$ (stannite) and $\mathrm{Cu}_{2} \mathrm{ZnSnS}_{4}$ (kesterite)," Physics and Chemistry of Minerals, vol. 27, no. 7, pp. 453-461, 2000.

[16] I. D. Olekseyuk, L. D. Gulay, I. V. Dydchak, L. V. Piskach, O. V. Parasyuk, and O. V. Marchuk, "Single crystal preparation and crystal structure of the $\mathrm{Cu}_{2} \mathrm{Zn} / \mathrm{Cd}, \mathrm{Hg} / \mathrm{SnSe}_{4}$ compounds," Journal of Alloys and Compounds, vol. 340, no. 1-2, pp. 141-145, 2002.

[17] A. Nateprov, V. Ch. Kravtsov, G. Gurieva, and S. Schorr, "Single crystal X-ray structure investigation of $\mathrm{Cu}_{2} \mathrm{ZnSnSe}_{4}$," Surface Engineering and Applied Electrochemistry, vol. 49, no. 5, pp. 423426, 2013.

[18] S. Schorr, H.-J. Hoebler, and M. Tovar, "A neutron diffraction study of the stannite-kesterite solid solution series," European Journal of Mineralogy, vol. 19, no. 1, pp. 65-73, 2007.

[19] S. Schorr, "The crystal structure of kesterite type compounds: a neutron and X-ray diffraction study," Solar Energy Materials and Solar Cells, vol. 95, no. 6, pp. 1482-1488, 2011.

[20] C. Persson, "Electronic and optical properties of $\mathrm{Cu}_{2} \mathrm{ZnSnS}_{4}$ and $\mathrm{Cu}_{2} \mathrm{ZnSnSe}_{4}$," Journal of Applied Physics, vol. 107, no. 5, Article ID 053710, 2010.
[21] J. Vidal, S. Botti, P. Olsson, J.-F. Guillemoles, and L. Reining, "Strong interplay between structure and electronic properties in $\mathrm{CuIn}(\mathrm{S}, \mathrm{Se})_{2}$ : a first-principles study," Physical Review Letters, vol. 104, no. 5, Article ID 056401, 2010.

[22] J. Paier, R. Asahi, A. Nagoya, and G. Kresse, " $\mathrm{Cu}_{2} \mathrm{ZnSnS}_{4}$ as a potential photovoltaic material: a hybrid Hartree-Fock density functional theory study," Physical Review B, vol. 79, no. 11, Article ID 115126, 2009.

[23] S. Chen, A. Walsh, J. H. Yang et al., "Compositional dependence of structural and electronic properties of $\mathrm{Cu}_{2} \mathrm{ZnSn}(\mathrm{S}, \mathrm{Se})_{4}$ alloys for thin film solar cells," Physical Review B, vol. 83, Article ID 125201, 2011.

[24] I. D. Olekseyuk, I. V. Dudchak, and L. V. Piskach, "Phase equilibria in the $\mathrm{Cu}_{2} \mathrm{~S}-\mathrm{ZnS}-\mathrm{SnS}_{2}$ system," Journal of Alloys and Compounds, vol. 368, no. 1-2, pp. 135-143, 2004.

[25] I. V. Dudchak and L. V. Piskach, "Phase equilibria in the $\mathrm{Cu}_{2} \mathrm{SnSe}_{3}-\mathrm{SnSe}_{2}-\mathrm{ZnSe}$ system," Journal of Alloys and Compounds, vol. 351, no. 1-2, pp. 145-150, 2003.

[26] I. D. Olekseyuk, I. V. Dudchak, and L. V. Piskach, "Phase equlibrium in the quazythird-timed system $\mathrm{Cu}_{2} \mathrm{Se}-\mathrm{ZnSe}-\mathrm{Cu}_{2} \mathrm{SnSe}_{3}$," Physics and Chemistry of Solid State, no. 1, pp. 195-200, 2001.

[27] A. Nagoya, R. Asahi, R. Wahl, and G. Kresse, "Defect formation and phase stability of $\mathrm{Cu}_{2} \mathrm{ZnSnS}_{4}$ photovoltaic material," Physical Review B, vol. 81, no. 11, Article ID 113202, 2010.

[28] A. Nagoya, R. Asahi, and G. Kresse, "First-principles study of $\mathrm{Cu}_{2} \mathrm{ZnSnS}_{4}$ and the related band offsets for photovoltaic applications," Journal of Physics Condensed Matter, vol. 23, no. 40, Article ID 404203, 2011.

[29] H. Katagiri, K. Jimbo, M. Tahara, H. Araki, and K. Oishi, "The influence of the composition ratio on CZTS-based thin film solar cells," in MRS Spring Meeting, pp. 125-136, April 2009.

[30] S. Ahn, S. Jung, J. Gwak et al., "Determination of band gap energy (Eg) of $\mathrm{Cu}_{2} \mathrm{ZnSnSe}_{4}$ thin films: on the discrepancies of reported band gap values," Applied Physics Letters, vol. 97, no. 2, Article ID 021905, 2010.

[31] A. Redinger, D. M. Berg, P. J. Dale et al., "Route toward high-efficiency single-phase $\mathrm{Cu}_{2} \mathrm{ZnSn}(\mathrm{S}, \mathrm{Se})_{4}$ thin-film solar cells:model experiments and literature review," IEEE Journal of Photovoltaics, vol. 1, no. 2, pp. 200-206, 2011.

[32] A. Redinger, K. Hönes, X. Fontań et al., "Detection of a ZnSe secondary phase in coevaporated $\mathrm{Cu}_{2} \mathrm{ZnSnSe}_{4}$ thin films," Applied Physics Letters, vol. 98, no. 10, Article ID 101907, 2011.

[33] Y.-T. Zhai, S. Chen, J.-H. Yang et al., "Structural diversity and electronic properties of $\mathrm{Cu}_{2} \mathrm{SnX}_{3}(\mathrm{X}=\mathrm{S}, \mathrm{Se})$ : a first-principles investigation," Physical Review B, vol. 84, no. 7, Article ID 075213, 2011.

[34] S. Schorr and G. Geandier, "In-situ investigation of the temperature dependent structural phase transition in $\mathrm{CuInSe}_{2}$ by synchrotron radiation," Crystal Research and Technology, vol. 41, no. 5, pp. 450-457, 2006.

[35] S. Schorr, G. Geandier, and B. V. Korzun, "Some are different from others: high temperature structural phase transitions in ternary chalcopyrites," Physica Status Solidi C, vol. 3, no. 8, pp. 2610-2613, 2006.

[36] S. Schorr and G. Gonzalez-Aviles, "In-situ investigation of the structural phase transition in kesterite," Physica Status Solidi A, vol. 206, no. 5, pp. 1054-1058, 2009.

[37] S. N. Sahu, R. K. Pandey, and S. Chandra, Handbook of Semiconductor Electrodeposition, Marcel Dekker, New York, 1996. 
[38] D. Lincot, "Electrodeposition of semiconductors," Thin Solid Films, vol. 487, no. 1-2, pp. 40-48, 2005.

[39] D. Lincot, J. F. Guillemoles, S. Taunier et al., "Chalcopyrite thin film solar cells by electrodeposition," Solar Energy, vol. 77, no. 6, pp. 725-737, 2004.

[40] D. Cunningham, M. Rubcich, and D. Skinner, "Cadmium telluride PV module manufacturing at BP solar," Progress in Photovoltaics: Research and Applications, vol. 10, no. 2, pp. 159168, 2002.

[41] B. E. McCandless, A. Mondal, and R. W. Birkmire, "Galvanic deposition of cadmium sulfide thin films," Solar Energy Materials and Solar Cells, vol. 36, no. 4, pp. 369-379, 1995.

[42] J. J. Scragg, P. J. Dale, and L. M. Peter, “Towards sustainable materials for solar energy conversion: preparation and photoelectrochemical characterization of $\mathrm{Cu}_{2} \mathrm{ZnSnS}_{4}$, Electrochemistry Communications, vol. 10, no. 4, pp. 639-642, 2008.

[43] J. J. Scragg, P. J. Dale, and L. M. Peter, "Synthesis and characterization of $\mathrm{Cu}_{2} \mathrm{ZnSnS}_{4}$ absorber layers by an electrodepositionannealing route," Thin Solid Films, vol. 517, no. 7, pp. 2481-2484, 2009.

[44] J. J. Scragg, P. J. Dale, L. M. Peter, G. Zoppi, and I. Forbes, "New routes to sustainable photovoltaics: evaluation of $\mathrm{Cu}_{2} \mathrm{ZnSnS}_{4}$ as an alternative absorber material," Physica Status Solidi B, vol. 245, no. 9, pp. 1772-1778, 2008.

[45] J. J. Scragg, D. M. Berg, and P. J. Dale, "A 3.2\% efficient Kesterite device from electrodeposited stacked elemental layers," Journal of Electroanalytical Chemistry, vol. 646, no. 1-2, pp. 52-59, 2010.

[46] H. Araki, Y. Kubo, A. Mikaduki et al., "Preparation of $\mathrm{Cu}_{2} \mathrm{ZnSnS}_{4}$ thin films by sulfurizing electroplated precursors," Solar Energy Materials and Solar Cells, vol. 93, no. 6-7, pp. 996999, 2009.

[47] H. Araki, Y. Kubo, K. Jimbo et al., "Preparation of $\mathrm{Cu}_{2} \mathrm{ZnSnS}_{4}$ thin films by sulfurization of co-electroplated $\mathrm{Cu}-\mathrm{Zn}$-Sn precursors," Physica Status Solidi C, vol. 6, no. 5, pp. 1266-1268, 2009.

[48] R. Schurr, A. Hölzing, S. Jost et al., "The crystallisation of $\mathrm{Cu}_{2} \mathrm{ZnSnS}_{4}$ thin film solar cell absorbers from co-electroplated $\mathrm{Cu}-\mathrm{Zn}$-Sn precursors," Thin Solid Films, vol. 517, no. 7, pp. 24652468, 2009.

[49] Q. Guo, H. W. Hillhouse, and R. Agrawal, "Synthesis of $\mathrm{Cu}_{2} \mathrm{ZnSnS}_{4}$ nanocrystal ink and its use for solar cells," Journal of the American Chemical Society, vol. 131, no. 33, pp. 11672-11673, 2009.

[50] S. Ahmed, K. B. Reuter, O. Gunawan, L. Guo, L. T. Romankiw, and H. Deligianni, "A high efficiency electrodeposited $\mathrm{Cu}_{2} \mathrm{ZnSnS}_{4}$ solar cell," Advanced Energy Materials, vol. 2, no. 2, pp. 253-259, 2012.

[51] N. M. Shinde, D. P. Dubal, D. S. Dhawale, C. D. Lokhande, J. H. Kim, and J. H. Moon, "Room temperature novel chemical synthesis of $\mathrm{Cu}_{2} \mathrm{ZnSnS}_{4}$ (CZTS) absorbing layer for photovoltaic application," Materials Research Bulletin, vol. 47, no. 2, pp. 302307, 2012.

[52] S. S. Mali, P. S. Shinde, C. A. Betty, P. N. Bhosale, Y. W. Oh, and P. S. Patil, "Synthesis and characterization of $\mathrm{Cu}_{2} \mathrm{ZnSnS}_{4}$ thin films by SILAR method," Journal of Physics and Chemistry of Solids, vol. 73, no. 6, pp. 735-740, 2012.

[53] S. S. Mali, B. M. Patil, C. A. Betty et al., "Novel synthesis of kesterite $\mathrm{Cu}_{2} \mathrm{ZnSnS}_{4}$ nanoflakes by successive ionic layer adsorption and reaction technique: characterization and application," Electrochimica Acta, vol. 66, pp. 261-221, 2012.
[54] T. Washio, T. Shinji, S. Tajima et al., “6\% Efficiency $\mathrm{Cu}_{2} \mathrm{ZnSnS}_{4}$ based thin film solar cells using oxide precursors by open atmosphere type CVD," Journal of Materials Chemistry, vol. 22, no. 9, pp. 4021-4024, 2012.

[55] H. Katagiri, K. Saitoh, T. Washio, H. Shinohara, T. Kurumadani, and S. Miyajima, "Development of thin film solar cell based on $\mathrm{Cu}_{2} \mathrm{ZnSnS}_{4}$ thin films," Solar Energy Materials and Solar Cells, vol. 65, no. 1, pp. 141-148, 2001.

[56] H. Katagiri, K. Jimbo, K. Moriya, and K. Tsuchida, "Solar cell without environmental pollution by using CZTS thin film," in Proceddings of the 3rd World Conference on Photovoltaic Energy Conversion, vol. 2873, pp. 2874-2879, May 2003.

[57] T. M. Friedlmeier, H. Dittrich, and H. W. Schock, "Growth and characterization of $\mathrm{Cu}_{2} \mathrm{ZnSnS}_{4}$ and $\mathrm{Cu}_{2} \mathrm{ZnSnSe}_{4}$ thin films for photovoltaic applications," in Ternary and Multinary Compounds, R. D. Tomlinson, A. E. Hill, and R. D. Pilkington, Eds., pp. 345-348, Lop Publishing, Bristol, UK, 1998.

[58] T. M. Friedlmeier, N. Wieser, T. Walter, H. Dittrich, and H.-D. Schock, "Heterojunctions based on $\mathrm{Cu}_{2} \mathrm{ZnSnS}_{4}$ and $\mathrm{Cu}_{2} \mathrm{ZnSnSe}_{4}$ thin films," in Proceedings of the 14th European Photovoltaic Solar Energy Conference, pp. 1242-1245, 1997.

[59] P. Jackson, D. Hariskos, E. Lotter et al., "New world record efficiency for $\mathrm{Cu}(\mathrm{In}, \mathrm{Ga}) \mathrm{Se}_{2}$ thin-film solar cells beyond $20 \%$," Progress in Photovoltaics: Research and Applications, vol. 19, no. 7, pp. 894-897, 2011.

[60] A. Weber, H. Krauth, S. Perlt et al., "Multi-stage evaporation of $\mathrm{Cu}_{2} \mathrm{ZnSnS}_{4}$ thin films," Thin Solid Films, vol. 517, no. 7, pp. 25242526, 2009.

[61] T. Eisenbarth, R. Caballero, M. Nichterwitz, C. A. Kaufmann, H.-W. Schock, and T. Unold, "Characterization of metastabilities in $\mathrm{Cu}(\mathrm{In}, \mathrm{Ga}) \mathrm{Se}_{2}$ thin-film solar cells by capacitance and current-voltage spectroscopy," Journal of Applied Physics, vol. 110, no. 9, Article ID 094506, 2011.

[62] M. Igalson, A. Urbaniak, A. Krysztopa et al., "Sub-bandgap photoconductivity and photocapacitance in CIGS thin films and devices," Thin Solid Films, vol. 519, no. 21, pp. 7489-7492, 2011.

[63] V. Izquierdo-Roca, R. Caballero, X. Fontané et al., "Raman scattering analysis of $\mathrm{Cu}$-poor $\mathrm{Cu}(\mathrm{In}, \mathrm{Ga}) \mathrm{Se}_{2}$ cells fabricated on polyimide substrates: effect of $\mathrm{Na}$ content on microstructure and phase structure," Thin Solid Films, vol. 519, no. 21, pp. 73007303, 2011.

[64] A. Meeder, P. Schmidt-Weber, U. Hornauer et al., "High voltage $\mathrm{Cu}(\mathrm{In}, \mathrm{Ga}) \mathrm{S}_{2}$ solar modules," Thin Solid Films, vol. 519, no. 21, pp. 7534-7536, 2011.

[65] S. Merdes, R. Mainz, J. Klaer et al., "12.6\% efficient $\mathrm{CdS} / \mathrm{Cu}(\mathrm{In}, \mathrm{Ga}) \mathrm{S}_{2}$-based solar cell with an open circuit voltage of $879 \mathrm{mV}$ prepared by a rapid thermal process," Solar Energy Materials and Solar Cells, vol. 95, no. 3, pp. 864-869, 2011.

[66] H. Mönig, C. A. Kaufmann, C.-H. Fischer et al., "Gallium gradients in chalcopyrite thin films: depth profile analyses of films grown at different temperatures," Journal of Applied Physics, vol. 110, no. 9, Article ID 093509, 2011.

[67] I. Riedel, J. Riediger, J. Ohland et al., "Photoelectric characterization of $\mathrm{Cu}(\mathrm{In}, \mathrm{Ga}) \mathrm{S}_{2}$ solar cells obtained from rapid thermal processing at different temperatures," Solar Energy Materials and Solar Cells, vol. 95, no. 1, pp. 270-273, 2011.

[68] W. Li, S. Cohen, K. Gartsman et al., "Chemical compositional non-uniformity and its effects on CIGS solar cell performance at the nm-scale," Solar Energy Materials and Solar Cells, vol. 98, pp. 78-82, 2012. 
[69] M. Bär, B.-A. Schubert, B. Marsen et al., "Native oxidation and $\mathrm{Cu}$-poor surface structure of thin film $\mathrm{Cu}_{2} \mathrm{ZnSnS}_{4}$ solar cell absorbers," Applied Physics Letters, vol. 99, no. 11, Article ID 112103, 2011.

[70] M. Bär, B.-A. Schubert, B. Marsen et al., "Cliff-like conduction band offset and $\mathrm{KCN}$-induced recombination barrier enhancement at the $\mathrm{CdS} / \mathrm{Cu}_{2} \mathrm{ZnSnS}_{4}$ thin-film solar cell heterojunction," Applied Physics Letters, vol. 99, no. 22, Article ID 222105, 2011.

[71] P. A. Fernandes, P. M. P. Salomé, A. F. da Cunha, and B.-A. Schubert, " $\mathrm{Cu}_{2} \mathrm{ZnSnS}_{4}$ solar cells prepared with sulphurized dcsputtered stacked metallic precursors," Thin Solid Films, vol. 519, no. 21 , pp. $7382-7385,2011$.

[72] J. Just, D. Ltzenkirchen-Hecht, R. Frahm, S. Schorr, and T. Unold, "Determination of secondary phases in kesterite $\mathrm{Cu}_{2} \mathrm{ZnSnS}_{4}$ thin films by X-ray absorption near edge structure analysis," Applied Physics Letters, vol. 99, no. 26, Article ID 262105, 2011.

[73] B.-A. Schubert, B. Marsen, S. Cinque et al., " $\mathrm{Cu}_{2} \mathrm{ZnSnS}_{4}$ thin film solar cells by fast coevaporation," Progress in Photovoltaics: Research and Applications, vol. 19, no. 1, pp. 93-96, 2011.

[74] M. Bär, B.-A. Schubert, B. Marsen et al., "Impact of KCN etching on the chemical and electronic surface structure of $\mathrm{Cu}_{2} \mathrm{ZnSnS}_{4}$ thin-film solar cell absorbers," Applied Physics Letters, vol. 99, no. 15, Article ID 152111, 2011.

[75] K. Wang, O. Gunawan, T. Todorov et al., "Thermally evaporated $\mathrm{Cu}_{2} \mathrm{ZnSnS}_{4}$ solar cells," Applied Physics Letters, vol. 97, no. 14, Article ID 143508, 2010.

[76] B. Shin, O. Gunawan, Y. Zhu, N. A. Bojarczuk, S. J. Chey, and S. Guha, "Thin film solar cell with $8.4 \%$ power conversion efficiency using an earth-abundant $\mathrm{Cu}_{2} \mathrm{ZnSnS}_{4}$ absorber," Progress in Photovoltaics: Research and Applications, vol. 21, no. 1, pp. 7276, 2011.

[77] T. Tanaka, A. Yoshida, D. Saiki et al., "Influence of composition ratio on properties of $\mathrm{Cu}_{2} \mathrm{ZnSnS}_{4}$ thin films fabricated by coevaporation," Thin Solid Films, vol. 518, no. 21, pp. S29-S33, 2010.

[78] K. Moriya, K. Tanaka, and H. Uchiki, " $\mathrm{Cu}_{2} \mathrm{ZnSnS}_{4}$ thin films annealed in $\mathrm{H}_{2} \mathrm{~S}$ atmosphere for solar cell absorber prepared by pulsed laser deposition," Japanese Journal of Applied Physics, vol. 47, no. 1, pp. 602-604, 2008.

[79] K. Moriya, K. Tanaka, and H. Uchiki, "Fabrication of $\mathrm{Cu}_{2} \mathrm{Zn}$ $\mathrm{SnS}_{4}$ thin-film solar cell prepared by pulsed laser deposition," Japanese Journal of Applied Physics, vol. 46, no. 9A, pp. 57805781, 2007.

[80] Z. Yang, Research on one-step Preparation of CZTS films and electrochemical optical properties [M.S. thesis], Dalian University of Technology, 2011.

[81] N. Momose, M. T. Htay, T. Yudasaka et al., " $\mathrm{Cu}_{2} \mathrm{ZnSnS}_{4}$ thin film solar cells utilizing sulfurization of metallic precursor prepared by simultaneous sputtering of metal targets," Japanese Journal of Applied Physics, vol. 50, no. 1, Article ID 01BG09, 2011.

[82] K. Jimbo, R. Kimura, T. Kamimura et al., " $\mathrm{Cu}_{2} \mathrm{ZnSnS}_{4}$-type thin film solar cells using abundant materials," Thin Solid Films, vol. 515, no. 15, pp. 5997-5999, 2007.

[83] H. Katagiri, K. Jimbo, S. Yamada et al., "Enhanced conversion efficiencies of $\mathrm{Cu}_{2} \mathrm{ZnSnS}_{4}$-based thin film solar cells by using preferential etching technique," Applied Physics Express, vol. 1, no. 4, Article ID 041201, 2008.

[84] N. Muhunthan, O. P. Singh, S. Singh, and V. N. Singh, "Growth of CZTS thin films by cosputtering of metal targets and sulfurization in $\mathrm{H}_{2} \mathrm{~S}$, International Journal of Photoenergy, vol. 2013, Article ID 752012, 7 pages, 2013.
[85] A. Khalkar, K. S. Lim, S. M. Yu, S. P. Patole, and J. B. Yoo, "Effect of growth parameters and annealing atmosphere on the properties of $\mathrm{Cu}_{2} \mathrm{ZnSnS}_{4}$ thin films deposited by cosputtering," International Journal of Photoenergy, vol. 2013, Article ID 690165, 7 pages, 2013.

[86] S. Zhang, "CZTS thin film and it's research progress of solar cell," Engineering and Technology, no. 8, pp. 67-69, 2010.

[87] A. V. Moholkar, S. S. Shinde, A. R. Babar et al., "Development of CZTS thin films solar cells by pulsed laser deposition: influence of pulse repetition rate," Solar Energy, vol. 85, no. 7, pp. 13541363, 2011.

[88] K. Tanaka, M. Oonuki, N. Moritake, and H. Uchiki, " $\mathrm{Cu}_{2} \mathrm{ZnSnS}_{4}$ thin film solar cells prepared by non-vacuum processing," Solar Energy Materials and Solar Cells, vol. 93, no. 5, pp. 583-587, 2009.

[89] K. Tanaka, Y. Fukui, N. Moritake, and H. Uchiki, "Chemical composition dependence of morphological and optical properties of $\mathrm{Cu}_{2} \mathrm{ZnSnS}_{4}$ thin films deposited by sol-gel sulfurization and $\mathrm{Cu}_{2} \mathrm{ZnSnS}_{4}$ thin film solar cell efficiency," Solar Energy Materials and Solar Cells, vol. 95, no. 3, pp. 838-842, 2011.

[90] Q. Guo, G. M. Ford, W.-C. Yang et al., "Fabrication of 7.2\% efficient CZTSSe solar cells using CZTS nanocrystals," Journal of the American Chemical Society, vol. 132, no. 49, pp. 1738417386, 2010.

[91] T. K. Todorov, K. B. Reuter, and D. B. Mitzi, "High-efficiency solar cell with earth-abundant liquid-processed absorber," Advanced Materials, vol. 22, no. 20, pp. E156-E159, 2010.

[92] T. Todorov, O. Gunawan, S. J. Chey, T. G. De Monsabert, A. Prabhakar, and D. B. Mitzi, "Progress towards marketable earthabundant chalcogenide solar cells," Thin Solid Films, vol. 519, no. 21, pp. 7378-7381, 2011.

[93] D. B. Mitzi, T. K. Todorov, O. Gunawan et al., "Torwards marketable efficiency solution-processed kesterite and chalcopyrite photovoltaic devices," in Proceedings of the 35th IEEE Photovoltaic Specialists Conference (PVSC '10), pp. 640-645, June 2010.

[94] D. A. R. Barkhouse, O. Gunawan, T. Gokmen, T. K. Todorov, and D. B. Mitzi, "Device characteristics of a $10.1 \%$ hydrazineprocessed $\mathrm{Cu}_{2} \mathrm{ZnSn}(\mathrm{Se}, \mathrm{S})_{4}$ solar cell," Progress in Photovoltaics: Research and Applications, vol. 20, no. 1, pp. 6-11, 2012.

[95] W. Zhou and Y. Zhou, "The preparation for flower-shaped CZTS nano-particle by solvothermal method and representational structure," Chemical Research, no. 5, pp. 70-74, 2012.

[96] Z. Yang, Research for the preparation of CZTS films by electrochemical one-step method on ITO substrates and equipment introduction [M.S. thesis], Dalian University of Science and Technology, 2011.

[97] R. Hoffman, "Materials for CZTS photovoltaic devices," in The NNIN REU Research Accomplishments, pp. 82-83, 2009. 

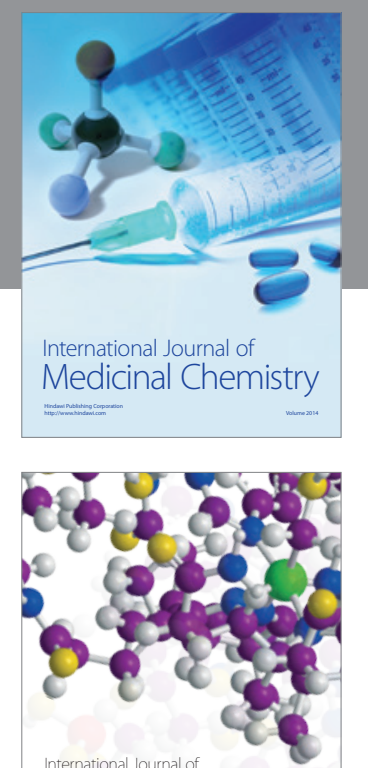

\section{Carbohydrate} Chemistry

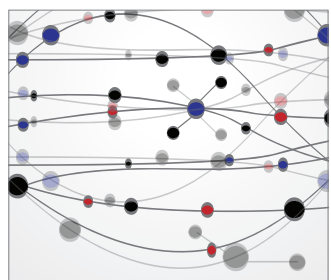

The Scientific World Journal
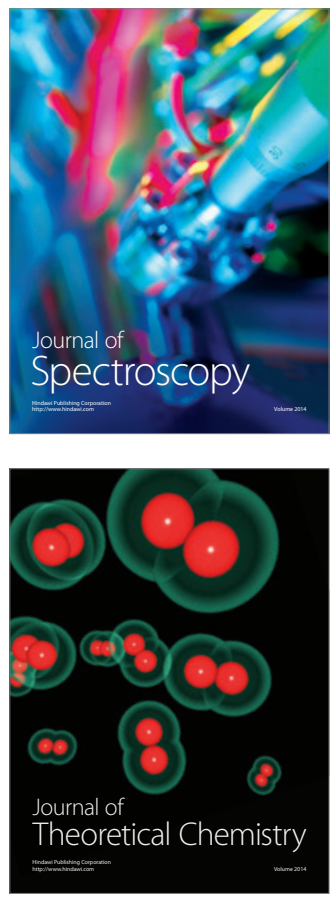
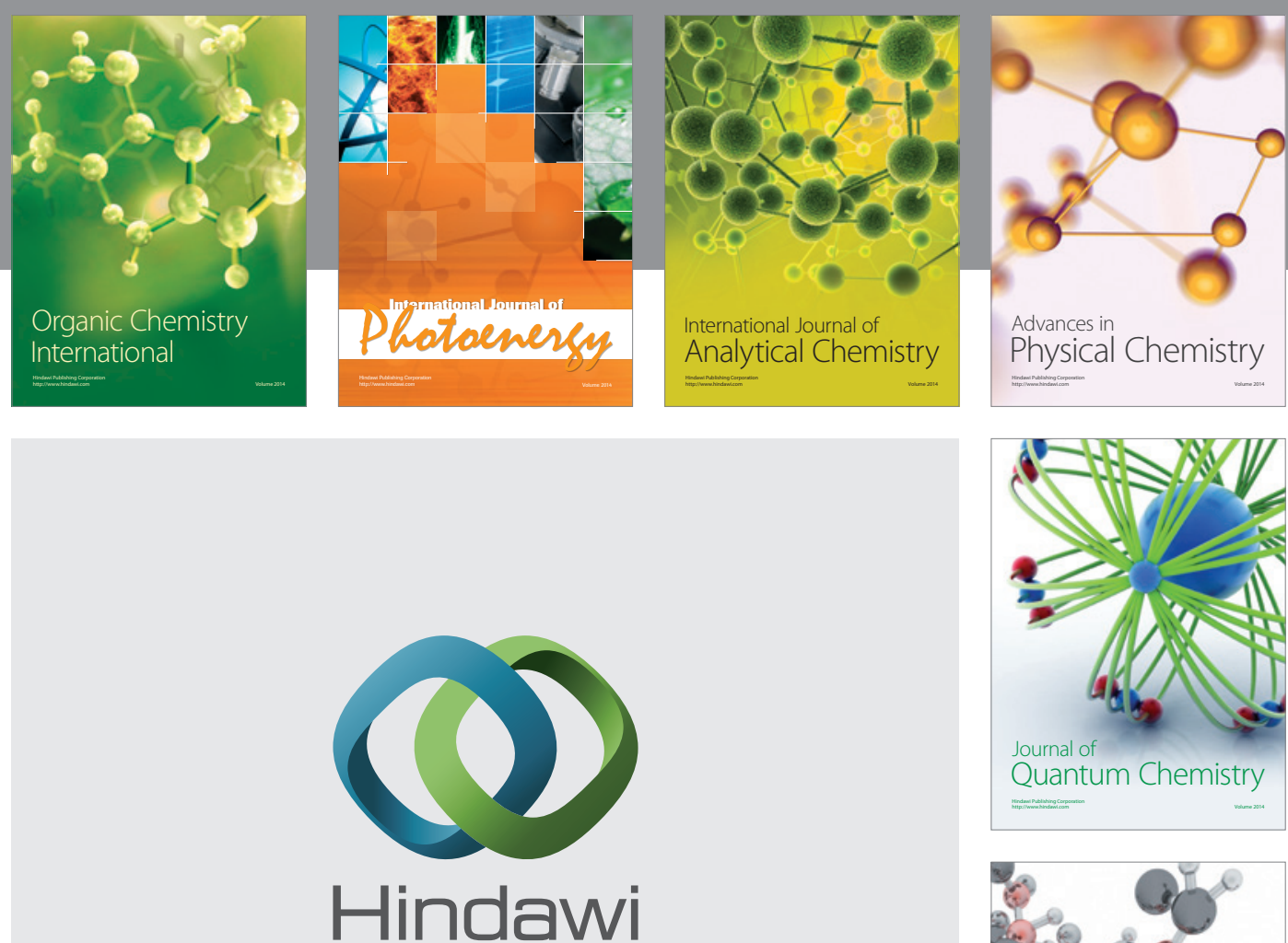

Submit your manuscripts at

http://www.hindawi.com

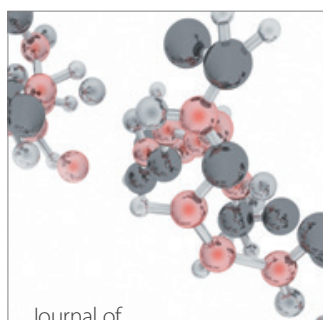

Analytical Methods

in Chemistry

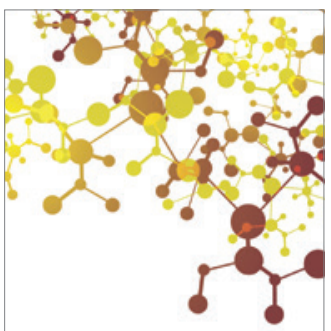

Journal of

Applied Chemistry

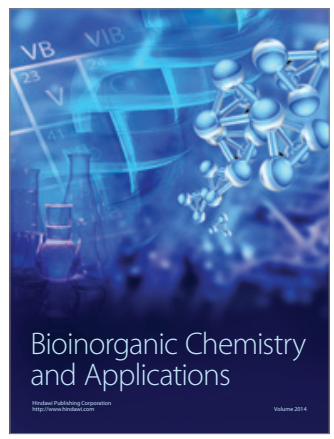

Inorganic Chemistry
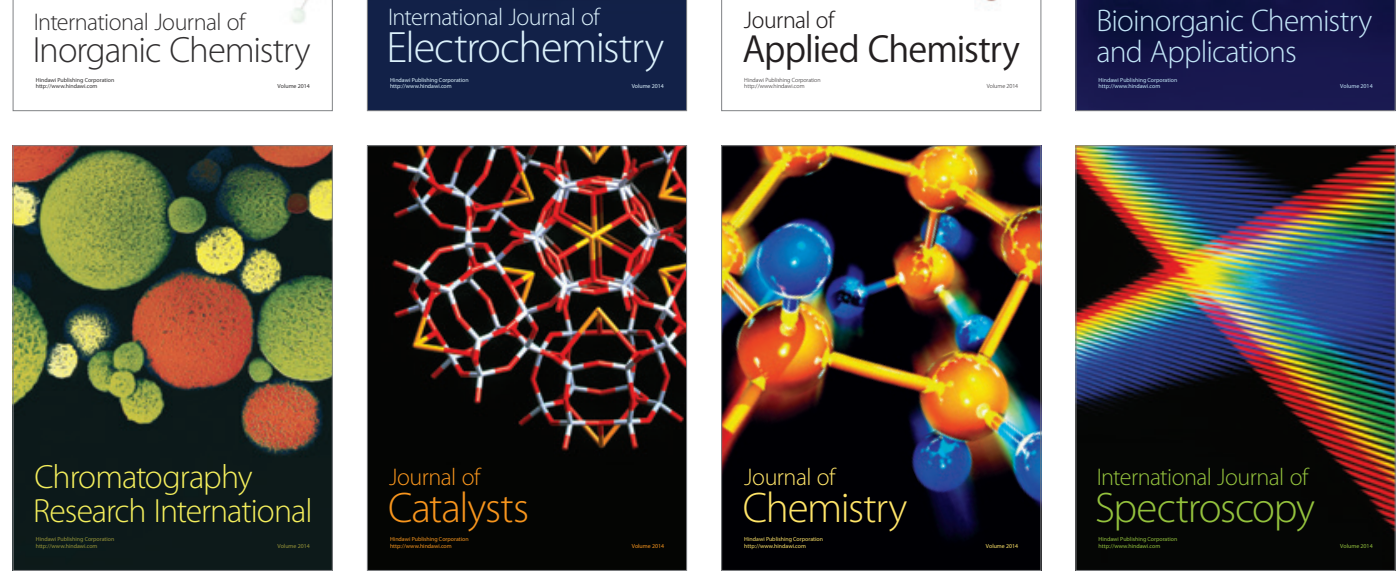